Bianca Elkington, Moana Jackson, Rebecca Kiddle, Ocean Ripeka

Mercier, Mike Ross, Jennie Smeaton \& Amanda Thomas

Imagining Decolonisation

Wellington, Bridget Williams Books, 2020, 184 pp

\title{
Imagining Beyond Decolonisation
}

\section{SIMON BARBER}

Difference must be not merely tolerated, but seen as a fund of necessary polarities between which our creativity can spark like a dialectic.

- Audre Lorde ${ }^{1}$

In an undergrad lecture I give on decolonisation, I begin, against the advice of Gayatri Spivak, by reading fiery quotes, ripped out of their context from Fanon's Wretched of the Earth. The opening sentences are as follows:

National liberation, national reawakening, restoration of the nation to the people or Commonwealth, whatever the name used, whatever the latest expression, decolonization is always a violent event. At whatever level we study it ... decolonization is quite simply the substitution of one 'species' of mankind by another. The substitution is unconditional, absolute, total, and seamless. ${ }^{2}$

'Species' here is both ironic, referencing the ways in

1 Audre Lorde, 'The Master's Tools Will Never Dismantle the Master's House,' in Sister Outsider: Essays and Speeches (Berkeley: Crossing Press, 2007), 110-114.

2 Frantz Fanon, The Wretched of the Earth, trans. Richard Philcox (New York: Grove Press, 2004), 1. 
which colonised people are racialised as inferior, and suggestive of how decolonisation, the process of struggle and liberation, itself produces a new human: 'the thing colonised becomes a man through the very process of liberation'. ${ }^{3}$ From the outset, Fanon leaves us in no doubt as to the necessary violence of decolonisation, pitched as it as against the far greater violence of colonisation.

So what remains of the old Fanonian meaning of decolonisation in the current proliferation of that term across public discourse? In my lecture, I follow Fanon by reading a series of tweets from Puawai Cairns, former head of Mātauranga Māori at Te Papa Tongarewa Museum of New Zealand, in which she takes the contemporary 'decolonial' vogue in institutions to task for really being about making white people feel better: 'Decolonisation is about supporting coloniser epiphanies, waiting for their humanisation of the native subject. Yet again. Which is why decol is just another col. We wait while you learn so you can resume control'. ${ }^{4}$ The point here is to highlight the drift in the concept, the way in which the idea of 'decolonisation' has started to break up or break down, how it has been captured by processes that serve to secure the continuation of colonisation. These two poles by no means exhaust decolonisation in its contemporary uses, but they provide useful coordinates for looking at what lies both between and beyond them.

If Imagining Decolonisation is not a manual for decolonisation in the older, Fanonian sense of the term, and certainly not what we might call 'imagined decolonisation'-decolonisation as a function of settler ideology that secures and maintains colonial structures-it does not fit neatly on a continuum between these two poles. In fact, the title is something of a misnomer. The various contributors all seem to be working towards the construction of a new concept, more adequate to our context in Aotearoa New Zealand, one that might take the place of 'decolonisation'. As indicated by the active verb 'imagining', the book offers a primer for those who might wish to join the necessarily collective process of envisioning how we move through where we are now to something better. It is an invition to join,

3 Fanon, Wretched of the Earth, 2.

4 Puawai Cairns (@Puawai Cairns), Twitter, 4 June 2019. 
to add to, to be taken over by a vision of a future we might wish for and work towards. In this, and many other regards, Imagining Decolonisation is undoubtedly a generous book. In this spirit, what follows is less a review and more an attempt to think alongside the authors it collects. I begin by drawing out some strands of the whakapapa of decolonisation in Aotearoa New Zealand.

If the Fanonian mode of decolonisation now seems more extreme than is required by our context, this has not always been the case. Following spectacular defeats at the hands of Riwha Tìtokowaru in 1868, with the fledgling colony drowning in debt, the high tide of the liberation struggle led by Te Kooti Arikirangi Te Türuki came very close to making ongoing European settlement of Aotearoa impossible. ${ }^{5}$ This was decolonial struggle in the original, Fanonian sense of the term; indeed, the British government itself was demanding that the colonial administration 'cede the lands conquered by the Queen's troops and ... recognise Māori authority'. ${ }^{6}$ Māori struggle in this period was also internationalist in its connections. In 1863, the year in which the settler state began the murderous land grab known as the Waikato Invasion, and a couple of years before Te Kooti's arrest for spying on behalf of the Hauhau uprising, Te Hokioi, the newspaper of the Kingitanga movement, published a series of articles providing a historical account of the Haitian Revolution. ${ }^{7}$ These articles referred to the black people of Haiti as Māori, and were framed as a cautionary tale for Pākehā. The author of the articles, Wiremu Pātara Te Tuhi, wrote:

No te tau 1804 , ka panuitia e taua iwi ta ratou whakaaro ki te ao katoa no to ratou wehenga, I te mana wiwi, me ta ratou puru i te tikanga hoko whenua. ... Inaianei kua whai ture taua motu kua pumau tona Rangatiratanga, kua tare ona Kara, tenei ano e mahi ana nga runanga o reira mo te pai o to ratou

5 James Belich, Making Peoples: A History of the New Zealanders from Polynesian Settlement to the End of the Nineteenth Century (Auckland: Penguin Books, 1996), 240. 6 Judith Binney, Redemption Songs: A Life of Te Kooti Arikirangi Te Turuki, (Honolulu: University of Hawai'i Press, 1997), 179.

7 Lachlan Paterson, Ngā Reo o Ngā Niupepa: Mãori Language Newspapers 1855-1863

(PhD diss., University of Otago, 2004), 131. 
whenua. Ko nga rangatira o Haiti kua whakakotahitia ta ratou kupu; ko te ture kua mana; ko ta ratou wa-apu maha noa iho kua whai moni.

(In the year 1804, [the Haitians] announced their idea to the whole world, of their separation from French mana, and their [intention to] stop the practice of land sales. ... Now that island has law and its rangatiratanga is secure. Its flags have flown, and the rūnanga of that place work for the good of their country. The rangatira of Haiti have unified their word; the law is empowered; their many harbours are rich. $)^{8}$

Te Kooti's use of guerrilla tactics ended in 1872, as he sought refuge in the King Country. The unlikely success of military conflict against a much larger and better equipped force saw Māori struggle shift in strategy towards more pacifist modes of resistance.

In the late 1960s, with the long post-war boom beginning its decline, class conflict on the rise, a near planetary explosion of popular unrest, and the emergence of the New Left, Te Hokioi was resurrected as a newsletter of the Māori working class. ${ }^{9}$ Together with MOOHR (Māori Organisation on Human Rights), Te Hokioi formed a significant centre of renewed Māori struggle. ${ }^{10}$ Importantly, Māori political activity in this period was rooted in working-class militancy, allied to the Pākehā working class, and selfconsciously part of the New Left internationally. For Te Hokioi, in Evan Poata-Smith's account,

the fundamental contradiction in society was between labour and capital, between the workers on the one hand and the bosses and land owners on the other. Racism was seen to be an outcome of class inequality. In this regard the majority of Māori were seen as an oppressed section of the working class. [Te Hokioi and MOOHR] advocated a pan-racial struggle

8 Paterson, Ngā Reo o Ngā Niupepa, 132.

9 George Katsiaficas, The Global Imagination of 1968: Revolution and Counterrevolution (Oakland: PM Press, 2018).

10 Evan Te Ahu Poata-Smith, The Political Economy of Mãori Protest Politics, 19681995: A Marxist Analysis of the Roots of Màori Oppression and the Politics of Resistance (PhD diss., University of Otago, 2002), 174-177. 
along class lines as the most effective strategy for resolving racism and Māori inequality. ${ }^{11}$

The early 1970s saw the emergence of Ngā Tamatoa and the Polynesian Panthers, both of which drew influence from the Black Panther Party in the US, operating according to an analysis that saw racism and capitalism as dual sources of oppression. The unwillingness of the Labour Party to halt ongoing land alienation in the 1970s led political activists to seek more direct political action, which found expression in the Land Rights Movement. Although opinion had begun to polarise around the question of revolution or reform, the Land March tied the struggle of Māori to that of the working class more generally. As Te Rōpū o te Matakite, the organising committee for the Land March in 1975, put it:

We see no difference between the aspirations of Māori people and the desire of workers in their struggles. We seek the support of workers and organisations, as the only viable bodies which have sympathy and understanding of the Mãori people and their desires. The people who are oppressing the workers are the same who are exploiting the Māori today. ${ }^{12}$

The occupations of Bastion Point and Raglan golf course were flash points of an increased radicality that could still be considered decolonial—inasmuch as they repossessed the land - as well as having broad working-class support (the Auckland Trades Council issued a ban on any work on the proposed development at Bastion Point).

The late 1970s onwards saw the emergence of the New Right internationally - the ruling-class counter-offensive against working-class militancy. The New Right was consecrated in Aotearoa New Zealand by the Lange government, who implemented neoliberal reforms at break-neck speed, radically diminishing the power of the union movement. Ascendant neoliberalism was accompanied by a fundamental shift in the ideological

11 Poata-Smith, The Political Economy of Mãori Protest, 174-175.

12 Te Rōpū o te Matakite, 'Petition of Support: Maori Land March on Parliament,' The Otago Daily Times, 20 September 1975. 
orientation of Māori struggle. Crucial to this shift was the Waitangi Tribunal process, which served to increase class stratification within Māori society by way of the production of a conservative Māori elite. ${ }^{13}$ Where Māori struggle had previously positioned itself within working-class struggle more generally, a new basis in cultural nationalism called for Māori unity over and above class solidarities. ${ }^{14}$ Previously, racism was taken to be an integral component of the operations of capital accumulation, implemented and maintained by a racist and capitalist state. For cultural nationalism, however, the less determinate 'Pākehā culture' was taken to be the source of oppression, unified Māori culture the remedy.

For Poata-Smith, while the re-founding of Māori struggle on a basis of cultural nationalism has been an expedient strategy for Māori professionals, business executives, and tribal capitalists, it has been disastrous for workingclass Māori whānau. ${ }^{15}$ Cultural nationalism ignores the location of the majority of Māori within the working class and so ignores their objective interest in abolishing capitalism. It also ignores class divisions within Māori society and so ignores the different and conflicting class interests that result, doing the same for 'Pākehā society', which it deems a unity. It thus defines the struggle against oppression as one between Māori and Pākehā, and so forecloses the possibility of building a mass movement across these divisions. To retain logical coherence, it must render all other antagonisms (for example, class and gender) as subordinate to that between Māori and Pākehā. Instead of racial capitalism, an altogether more nebulous target is blamed: Pākehā culture.

The point of this historical detour is not to relitigate what paths should or should not have been taken, especially without regard to the way in which the movement was shaped by its broader material conditions. Indeed, the cultural turn has produced significant gains, especially in language and education. But despite all this, material inequality has increased, and Māori

13 Poata-Smith, The Political Economy of Mãori Protest, 18-19.

14 Poata-Smith, The Political Economy of Mãori Protest, 16-17.

15 Poata-Smith, The Political Economy of Mãori Protest, 20. 
are still held at the bottom of our economic hierarchy. ${ }^{16}$ Further, with few still prepared to defend neoliberalism, elements of it remain in the mainstream political common-sense. Likewise, there has not been a fundamental break from the strategy of cultural nationalism, even though it has softened and been co-opted as a language of appeasement by institutions of the state. In its institutionalised form, 'decolonisation' becomes the Orwellian cutural drag of state agenecies like Oranga Tamariki, a Ministry of Love as a machine for the theft of our children.

If we think of this latter mode of decolonisation as the paradoxical settler-state-led 'decolonisation' from above, is there a more robust sense of decolonisation circulating in activist scenes today? While better than 'decolonisation' from above, the currently dominant notion that Pākehā must in all instances defer to Māori on issues of decolonisation-and this is a potentially controversial point-is perhaps the most refined form of a paralysing guilt. This is not to say that guilt is wrong in any sense, but that it blocks the transformative energies that will be needed if we are to move on from the stasis of our still-violent, still-colonial present. I am not sure anyone can put their heart into something if they are designated in advance to the backseat. And why should Māori always have to do everything? Perhaps a better way to think about it is that the people with the most mana should lead. This has been the case at Ihumātao, for instance, and mana whenua is of course a paramount source of mana. Māori are tangata whenua and so it is tikanga Māori that should set the frame for the process of our interaction. But, as with the marae, the point is not to snuff out anyone's agency or refuse them full expression and participation. This might seem like much the same thing couched in different terms. The difference is perhaps subtle, but it returns us to a more fluid understanding of our relationships to each other, and does so on a healthier foundation.

This guilt is refined in a second sense. Being able to inhabit a sufficiently woke decolonial disposition becomes an abstract exercise, often absent of

16 Steve Matthewman, 'Pākehā Ethnicity: The Politics of White Privilege,' in $A$ Land of Milk and Honey? Making Sense of Aotearoa New Zealand, eds. Avril Bell et al (Auckland: Auckland University Press, 2017), 83-94. 
any interaction with Māori and accessible to only those with sufficient time and money. In this situation, white ally-ship becomes not just a closed circuit of unresolvable guilt but an exclusionary performance, a signifier of cultural capital that is in practice more effective for the advancement of Pākehā careers than those of Māori. And this is not to say that the current institutional fashion of brown-washing has no implications regarding class within Māori society. As Stan Coster, someone who, from childhood, has spent a significant amount of his life as a ward of the state, has said, obliquely referencing institutionalised forms of mātauranga Māori:

I don't know the Māori ways. There were two world wars. They took the old people ... no-one left to teach us. ... Our own people fucked us over 'cos they sold out and gave away to the Pākehā. Our land went, so did our heritage. . . . How do you learn about being Māori? . . . The only system I know, the old way, the hori (poor Māori) way, was to do whatever we wanted when we wanted. ${ }^{17}$

We must reject notions of ally-ship that, however well intentioned, retain a kernel of charity, replacing it instead with an active comradeship wherein we understand that our own liberation is inextricably bound to that of other's. I am drawn back to a quote from the Gangulu artist, activist, and philosopher Lilla Watson: 'If you have come here to help me, you are wasting your time. But if you have come because your liberation is bound up with mine, then let us work together'. ${ }^{18}$

And here, te ao Māori has something to teach Pākehā-about time and memory, about how past colonisation relates to present, about how we all relate to the actions of our ancestors. In te ao Māori, there is a sense that we are our ancestors, re-actualised in the present. For example, when a kaikōrero speaks on the marae, they give voice to the ancestors. Whakapapa is the continuous breath that flows from the tupuna through us and into

17 Tracey McIntosh and Stan Coster, 'Indigenous Insider Knowledge and Prison Identity,' Counterfutures 3 (2017): 88.

18 Quoted in Tracey McIntosh, 'Wāhine Māori and Prison,' Winter Lecture Series, University of Auckland, 3 August 2020. 
our mokopuna. This relationship returns us to a more social relationship with our pasts and allows us to take responsibility for them in a more active way. Colonisation becomes less some forgone event from which follows an irreparable, unatonable guilt (or the common view that we must put it behind us), and instead something alive, ongoing, that we can intervene in. So even though the aim is not decolonisation as the expulsion of Pākehāeven Donna Awatere in her most Fanonian phase said that Pākehā only thought that Māori wanted this because they assume everyone else is as violent as them!- colonisation could still be brought to a close. ${ }^{19}$ For this latter project, there are undoubtedly tasks that Pākehā can and should be the rangatira of.

In a lecture to students following the publication of The Fire Last Time, James Baldwin was asked to clarify what he meant by his claim that it is not that 'the whites must accept the Negroes but that the Negroes must accept the whites'.$^{20}$ His answer was to point to the fact that the hatred directed at black people has nothing to do with black people themselves. It is instead a violence internal to whiteness and something that white people must reckon with. Here, framings that dwell at the level of the personal suggest that healing this violence might be something that could be achieved by individual choice, forgetting the social basis of thought. Whiteness is a historical construction and one forged in service of the reproduction of the hierarchies of racial capitalism. Whiteness is an identity premised on that which it excludes so that it can dominate; the violence inside of white people is indelibly tied to the racial category of whiteness itself. Whiteness is irredemable and must be abolished. ${ }^{21}$ The term Pākehā has a different whakapapa. It is a relational term that names the difference of Europeans as percieved by Māori, the latter meaning 'normal' or 'like us'. As such, to be Pākehā offers the possibility of a much healthier alternative to being

19 Donna Awatere, Maori Sovereignty (Auckland: Broadsheet, 1984).

20 'James Baldwin Speaks! The Fire This Time: A Message to Black Youth,' YouTube (video), 25 May 2015.

21 Viewpoint Magazine, 'Beyond Guilt and Privilege: Abolishing the White Race,' Viewpoint, 5 August 2020. 
invested in the category of whiteness.

In Aotearoa New Zealand, the settler common-sense that allows for the continuation of the subordination of Māori as if it were somehow natural is produced through and across us, emanating from the structures and processes of our social organisation. The work to be done involves a process of non-elitist self-education. To rebuild the connections between working-class Pākehā and Māori, to develop a collective consciousness against race and against capital, and to develop forms of organising and organisations adequate to the task of abolishing them, is the patient work of our collective liberation and the construction of an identity that Pākehā might draw sustenance from instead of shame. Rather than being mediated via a state-led policy of abstract multiculturalism, the connections between us must be reforged and reorganised in terms that acknowledge Māori as tangata whenua whilst tearing down the hierarchies of racial capitalism.

However, the structure of our contemporary world limits our ability to envison that which lies beyond it. If decolonisation is an awkward name for the project of discerning and making our way to this beyond, then how might we better understand it? Imagining Decolonisation provides much of use for this task. In closing, I want to draw out a couple of strands that seem particularly fertile.

In the book's introduction, Bianca Elkington refers to her experiences in the Pākehā eduction system, and the subsequent work she took part in to build something like a counter-infrastructure-Te Puna Mātaurangathat works against the detrimental effects of a racist system. This work, remembering the insight from Fanon quoted above, is never only reactive but also fundamentally creative. In summarising her account, Elkington sketches out a definition of decolonisation suggestive of the beyond I have been referring too: 'there is much work to do, but when we know more, we do more. That knowing to me is an act of decolonisation'. ${ }^{22}$ This definition has an elegant simplicity appropriate for a broad readership. But perhaps it makes sense to abolish the division between knowing and doing altogether. Te Ahukaramū Charles Royal refers to mātauranga Māori as being more

22 Bianca Elkington et al, Imagining Decolonisation (Wellington: BWB, 2020), 12. 
akin to 'know-how': 'a sensuous and continuous interaction of experience and consciousness', something like the skilled activity of a craftsperson, wherein 'understanding and action flow seamlessly'. ${ }^{23} \mathrm{I}$ am not suggesting mātauranga is only ever about making things, or even doing things, but that it is an active type of knowing that refuses the very distinction between static knowledge and derivative action. How, then, do we begin to understand the know-how of a world that we must yet bring into being, one that is also the know-how of bringing that world into being?

Moana Jackson, in his brilliant closing essay, shows us how we might begin to answer this question. Rather than 'decolonisation', Jackson describes what he terms an 'ethic of restoration', a kind of know-how for setting things right. An ethic of restoration

would seek to replace colonisation not by merely deconstructing or culturally sensitising the attitudes and power structures that it has established, but by restoring a kawa that allows for balanced relationships based on the need for iwi and hapū independence upon which any meaningful interdependence must rest. Such an ethic derives from the lessons in the stories in the land about the potential to whakatika or to make right even the most egregious wrong, and to then whaka-papa, or build new relationships. To adapt it as a tool to create non-colonising relationships is to rekindle faith in the 'ought to be' in this land; to draw upon the same land-and tikanga-centred way of ordering society that was envisaged in Te Tiriti. ${ }^{24}$

The restoration of balance is, in the first instance, about constitutional transformation, which would restore full authority to tikanga as the first law of Aotearoa, allowing for the excercise of self-determination by iwi and hapū. Tikanga, developed over the long history of the intimate inhabitation

23 Te Ahukaramū Charles Royal, Let the World Speak: Towards Indigenous Epistemology (Porirua: Mauriora-ki-te-Ao/Living Universe, 2009), 5; Wânanga: The Creative Potential of Mãtauranga Māori (Porirua: Mauriora-ki-te-Ao/Living Universe, 2011), 12, 19.

\section{Imagining Decolonisation, 149.}


of, and interaction with, the whenua, asserts its own validity as an expression of this place. It is tika, 'just', in the dual sense of being both right and a good fit. Where the balance has been destroyed is in the refusal of Pākehā to acknowledge themselves as manuhiri, usurping authority and imposing a way of doing things alien to this place and its indigenous people. The need to ceaselessy cover over the groundlessness of Pākehā authority, or to repress the lack at the heart of Pakehā identity, often finds violent expression. In contrast, restoration generously holds open the possibility of a secure place to stand for Pākehā, a place from which Pākehā mana might also be restored. It is a redemptive and healing vision for Pākehā and Māori alike, one that we all might strive towards, though doing so from different sides of the marae. To pass under the waharoa and to enter te ao Marama, the world of light and relationships, Pākehā will have to relinquish an authority that was both never ours to take and damaging for us to hold. The work of relinquishing authority for Pākehā, and regaining it for Māori (I have a horse in each race), is the path towards the beyond that will be healthier for everyone, even if it might sting a little more for Pākehā at first. 